\title{
PELAKSANAAN HIGIENE PENJAMAH MAKANAN DAN SANITASI LINGKUNGAN DI INSTALASI GIZI RUMAH SAKIT HOLISTIC PURWAKARTA TAHUN 2016
}

\author{
Ela Nurseha ${ }^{1}$,Irwan Haryanto ${ }^{2}$, Dian Titis Torina ${ }^{3}$ \\ ${ }^{1,2}$ Sekolah Tinggi Ilmu Kesehatan Holistik Purwakarta \\ ${ }^{3}$ Rumah Sakit Holistic Purwakarta
}

\begin{abstract}
ABSTRAK
Latar belakang : Higiene dan sanitasi makanan di rumah sakit, kebersihan bahan makanan yang diolah sebagai makanan untuk pasien rawat inap. Penyakit yang ditularkan melalui makanan dapat menyebabkan penyakit yang ringan dan berat bahkan berakibat kematian diantaranya diakibatkan oleh belum baiknya penerapan SOP (Standart Oprating Procedure).

Tujuan:Mendeskripsikan upaya pelaksanaan higiene dan sanitasi di instalasi gizi rumah sakit holistic purwakarta.

Metode:Rancangan penelitianobservasional dengan desain deskriptif. subjek penelitian 13 penjamah makanan 2 ahli gizi dan 11 penjamah makanan. Data pelaksanaan higiene dan sanitasi instalasi gizi ditabulasi dan dianalisis secara deskriptif.

Hasil :Observasi higiene dan sanitasi $100 \%$ memmenuhi syarat Permenkes Nomor 1096/Menkes/Per/VI/2011 dan SOP(Standart Oprating procedure). Uji laik fisik untuk higiene sanitasi di instalasi gizi Rumah Sakit Holistic Purwakarta mendapatkan hasil 83 atau $92 \%$ sesuai dengan golongan B, minimal nilai 83 maksimal 92, atau rangking $83-92 \%$.

Simpulan :Sanitasi lingkungan dan higiene penjamah makanan sudah memenuhi syarat menurut Permenkes Nomor 1096/Menkes/Per/VI/2011 dan SOP (Standart Oprating procedure)pelaksanaan laik higiene dan sanitasi jasa boga golongan B, minimal nilai 83 maksimal 92, atau rangking $83-92 \%$.
\end{abstract}

Kata Kunci: Penjamah makanan, higiene dan sanitasi, rumah sakit holistic

\author{
Korespondensi : \\ Irwan Haryanto \\ Program Studi Ilmu Gizi, STIKes Holistik Purwakarta \\ Jl. Veteran No. 272 Ciseureuh Purwakarta, Jawa Barat 41118 \\ Email : irwanhyt@yahoo.com \\ Phone : 0852-9589-1738
}




\title{
IMPLEMENTATION OFFOOD HANDLER'S HYGIENEAND SANITATION IN HOLISTIC HOSPITAL'S NUTRITION INSTALLATION OF PURWAKARTA 2016
}

\begin{abstract}
Background: In food hygiene and sanitation activities in hospitals, hygiene of foodstuffs processed as food for inpatients. Diseases transmitted through food may cause mild disease and severe and even lead to death of them caused by the application has not been good as SOP (Standard oprating Procedure).

Objective: To describe efforts to implement hygiene and sanitation in the hospital holistic nutrition installation purwakarta.

Methods: The study design was observational descriptive design. 13 research subjects food handlers 2 nutritionists and 11 food handlers in the installation of Holistic Nutrition Hospital Purwakarta. Data execution of hygiene and sanitation installations home nutrition tabulated data and analyzed descriptively.

Results: The observation of hygiene and sanitation requirements $100 \%$ memmenuhi Decree No. 1096/Menkes/Per/VI/2011 and SOP (Standard oprating procedure). Physical acceptance tests for hygiene and sanitation at the plant nutrition Holistic Hospital Purwakarta getting the 83 or $92 \%$ according to the group $\mathrm{B}$, the minimum value of the maximum 8392 , or ranking $83-92 \%$.

Conclusion: Environmental sanitation: building, room food processing, sanitary aspects hospitals, materials sanitaiser, sanitaiser equipment and hygiene of food handlers: Health handlers, use of PPE, behavior penjamaha food already eligible under Decree No. 1096/Menkes/Per/VI/2011 and SOP (Standard oprating procedure). Acceptance and implementation of hygiene and sanitation jasanoga class $\mathrm{B}$, a minimum of 83 maximum value of 92 , or ranking $83-92 \%$.
\end{abstract}

Key words:Food handler, hygiene and sanitation, holistic hospital 


\section{PENDAHULUAN}

Pelayanan gizi rumah sakit (PGRS) merupakan bagian integral dari pelayanan kesehatan paripurna rumah sakit dengan beberapa kegiatan, antara lain asuhan gizi pasien rawat jalan, asuhan gizi pasien rawat inap, penyelenggaraan makanan, serta penelitian dan pengembangan gizi. ${ }^{1}$ Meningkatnya kebutuhan pasien terhadap makanan yang disediakan di rumah sakit, produk-produk yang disediakan oleh rumah sakit yang bergerak dalam usaha penyediaan makanan rumah sakit untuk kepentingan khusus (pasien rumah sakit), haruslah terjamin kesehatan dan keselamatannya. Sebagai salah satu jenis pelayanan khusus yang mengolah. Dengan demikian kualitas makanan yang dihasilkan dan disajikan oleh penjamah makanan harus memenuhi syarat kesehatan seperti faktor lokasi dan bangunan, fasilitas sanitasi, peralatan, pengolahan makanan dan personal higiene.

\begin{tabular}{lrr}
\multicolumn{1}{c}{ Penyakit yang ditularkan } \\
melalui makanan dapat \\
menyebabkan penyakit yang ringan
\end{tabular}

dan berat bahkan berakibat kematian diantaranya diakibatkan oleh belum baiknya penerapan SOP (Standart Oprating Procedure)higiene dan sanitasi di instalasi gizi. Karena itulah peneliti tertarik melakukan analisis mengenai pelaksanaan higien penjamah makanan dan sanitasi lingkungan di instalasi gizi Rumah Sakit Holistic Purwakarta.

\section{METODE}

Rancangan penelitian adalah observasional dengan desain deskriptif. ${ }^{2}$ Penelitianbangunan dan seluruh penjamah makanan. Sampel diambil dari populasi responden meliputi 2(dua) ahli gizi dan, 11 (sebelas) penjamah makanan di instalasi gizi. Dilaksanakan 4 (empat) hari. Teknik pengambilan sampel purposive sampling pengumpulan data meliputi fasilitas sanitasi, sanitasi bangunan, sanitasi ruangan pengolahan makanan, bahan sanitaiser, sanitaiser peralatan. Formulir terlampir pengolahan dan analisa data dalam penelitian ini adalah data pelaksanaan higiene penjamah makanan data ditabulasi dan di analisis secara deskriptif, data 
pelaksanaan sanitasi instalasi gizi rumah data ditabulasi dan di analisis secara deskriptif.

\section{HASIL PENELITIAN}

\section{Sanitasi Lingkungan Instalasi Gizi}

\section{a. Sanitasi Bangunan}

1) Lokasi

Dari hasil observasi di ketahui lokasi di Instalasi Gizi tidak berdekatan dengan tempat sampah umum dan WC umum lokasi dan sumber cemaran lainya. Lokasi instalasi gizi Rumah Sakit Holistic sudah memenuhi syarat lokasi instalasi gizi menurut Permenkes Nomor 1096/Menkes /Per/VI/2011 tentang higiene Sanitasi Jasaboga yaitu.

2) Halaman

Halaman Instalasi Gizi Rumah Sakit Holistic bersih dari barang-barang tidak dipakai dan menjadi sarang tikus, tidak ada sampah bersemak, tersedia tempat sampah. Pembuangan air limbah (air limbah dapur dan kamar mandi dan air hujan) sesuai dengan Permenkes Nomor 1096/Menkes/Per/VI/ 2011 tentang higiene sanitasi halaman Jasaboga.

3) Bangunan

Dari hasil observasi diketahui bangunan Instalasi Gizi Rumah Sakit Holistic sudah mememnuhi syarat Permenkes Nomor 1096/ Menkes/ Per/ VI/ 2011 tentang higiene sanitasi jasaboga.

4) Langit-langit atau atap

Dari hasil observasi di ketahui langit-langit atau atap Instalasi Gizi Rumah Sakit Holistic sudah memenuhi syarat diantaranya langitlangit atau atap tidak bocor, langit-langit atau atap berwarna terang dan mudah di bersihkan. Untuk langitlangit atau atap Instalasi Gizi Rumah Sakit Holiatic sudah memenuhi syarat sedangkan langit-langit atau atap menurut Permenkes Nomor 1096/Menkes /Per/VI/2011 
tentang higien sanitasi

jasaboga

5) Pintu dan Jendela

Dari hasil observasi diketahui bahwa jendela belum memenuhi syarat berdasarkan Permenkes Nomor

1096/Menkes/Per/VI/2011

tentang higiene sanitasi jasaboga, pintu dan jendela instalasi gizi Rumah Sakit Holistic terdapat pintu dan jendela rapat, mudah di bersihkan terbuat dari bahan yang kuat pembatas antar ruangan terdapat tirai rangkap yang dapat dibuka dan dipasang untuk dibersihkan. Tetapi pintu insatalasi gizi tidak dibuat membuka ke arah luar dan tidak dapat menutup sendiri (self closing).

6) Pencahayaan

Dari hasil observasi di ketahui pencahayaan instalasi gizi sudah memenuhi syarat, pencahayaan merata di setiap ruangan tidak menyilaukan pekerja dan dari hasil pemeriksaan dengan alat pengukur cahaya yaitu lux meter (Lx 1010b, Digital Lux Meter, 2000).

7) Ventilasi atau Penghawaan Dari hasil observasi di ketahui ventilasi atau Penghawaan di Instalasi Gizi tersedia empat Exhaust Fan yang berfungsi dengan baik dan cukup menjamin rasa nyaman oleh karena itu ventilasi atau penghawaan instalasi gizi rumah Sakit Holistic sesuai dengan Permenkes Nomor 1096/Menkes/Per/VI/2011 tentang higiene sanitasi jasaboga.

\section{b. Sanitasi Ruangan Pengolahan} Makanan

1) Lantai

Dari hasil observasi diketahui lantai di Instalasi Gizi bersih tidak licin menjamin rasa nyaman, kedap air, lantai rata mudah dibersihkan mempunya lubang pembuangan air. Oleh karna itu lantai Instalasi Gizi 
Rumah Sakit Holistic sesuai dengan peraturan Permenkes Nomor 1096/ Menkes/Per/VI/2011 tentang higiene sanitasi jasaboga.

2) Dinding

Dari hasil observasi di ketahui dinding di Instalasi Gizi bersih cerah, kedap air, dinding rata mudah di bersihkan, dinding yang terkena cipratan air dilapisi bahan kedap air setinggi $2 \mathrm{~m}^{2}$, tetapi sudut dinding dengan lantai tidak berbentuk lengkung (conus). Oleh karna itu dinding instalasi gizi rumah Sakit Holistic belum memenuhi Permenkes Nomor 1096/ Menkes/Per/VI/2011.

3) Gudang

Dari hasil observasi di ketahui gudang di Instalasi Gizi memiliki dua gudang yaitu gudang bahan kering dan gudang bahan basah di dalam gudang terjaga kebersihnya dan hanya tidak ada bahan lain selain bahan makanan, tersedia rak-rak penempatan bahan makanan sesuai dengan ketentuan, kapasitas gudang cukup memadai dan rapat dari tikus, tersedia pendingin (kulkas, freezer) Oleh karna itu gudang Instalasi Gizi Rumah Sakit Holistic sesuai dengan Permenkes Nomor 1096/Menkes/Per/VI/2011.

\section{c. Aspek Sanitasi Rumah Sakit.}

1) Tempat cuci tangan

Dari hasil observasi di ketahui tempat cuci tangan di Instalasi Gizi Rumah Sakit Holistic memiliki dua fasilitas cuci tangan tersedia air cuci tangan yang mencukupi, tersedia sabun (hand soap), deterjen dan alat pengering dan jumlah tempat cuci tangan cukup untuk pengunjung dan karyawan. Tempat cuci tangan Instalasi Gizi Rumah Sakit Holistic sesuai dengan Permenkes Nomor 1096/ Menkes/ Per/ VI/ 2011.

2) Air

Dari hasil observasi di ketahui air di Instalasi Gizi 
memiliki jumlah air mencukupi, air tidak berbau, tidak berasa dan tidak berwarna, bertekanan cukup air di instalasi gizi rumah Sakit Holistic sesuai dengan Permenkes Nomor 1096/ Menkes/Per/VI/2011.

3) Kamar mandi atau peturasan Dari hasil observasi di ketahui kamar mandi atau peturasan di Instalasi Gizi memiliki kamar mandi atau peturasan yang bersih, letaknya tidak berhubungan langsung dengan dapur, tersedia air bersih yang cukup tersedia sabun dan jumlah cukup. Kamar mandi atau peturasan di instalasi gizi rumah Sakit Holistic sesuai dengan Permenkes Nomor 1096/ Menkes/ Per/VI/2011.

4) Sampah

Dari hasil observasi di Instalasi Rumah Sakit Holistic tempat sampah diangkut setiap 24 jam, tersedia tempat sampah di ruangan penghasil sampah atau ruangan pengolahan dan ruangan pemorsian, tempat sampah di buat dari bahan kedap air dan kuat, tempat sampah dilapisi plastik yang di beri warna organik dan non organik, dan ukuran tempat sampah ergonomi tidak memberat pekerja, tetapi tempat sapah tidak memiliki tutup yang bisa di buka tutup. Tempat sampah di Instalasi Gizi Rumah Sakit Holistic sesuai dengan Permenkes Nomor 1096 /Menkes/ Per/VI/2011.

5) Pembagian Ruangan

Di dalam ruangan instalasi gizi dibagi beberapa ruangan dia antaranya ada ruangan karyawan, ruangan penerimaan barang, ruangan pengolahan, persiapan bahan, tersedia gudang penyimpanan bahan makanan kering dan basah, tersedia ruangan pembuatan jus, ruangan pemorsian, ruangan administrasi atau ruangan gizi dan ruangan pencucian peralatan. 


\section{d. Bahan Sanitaiser}

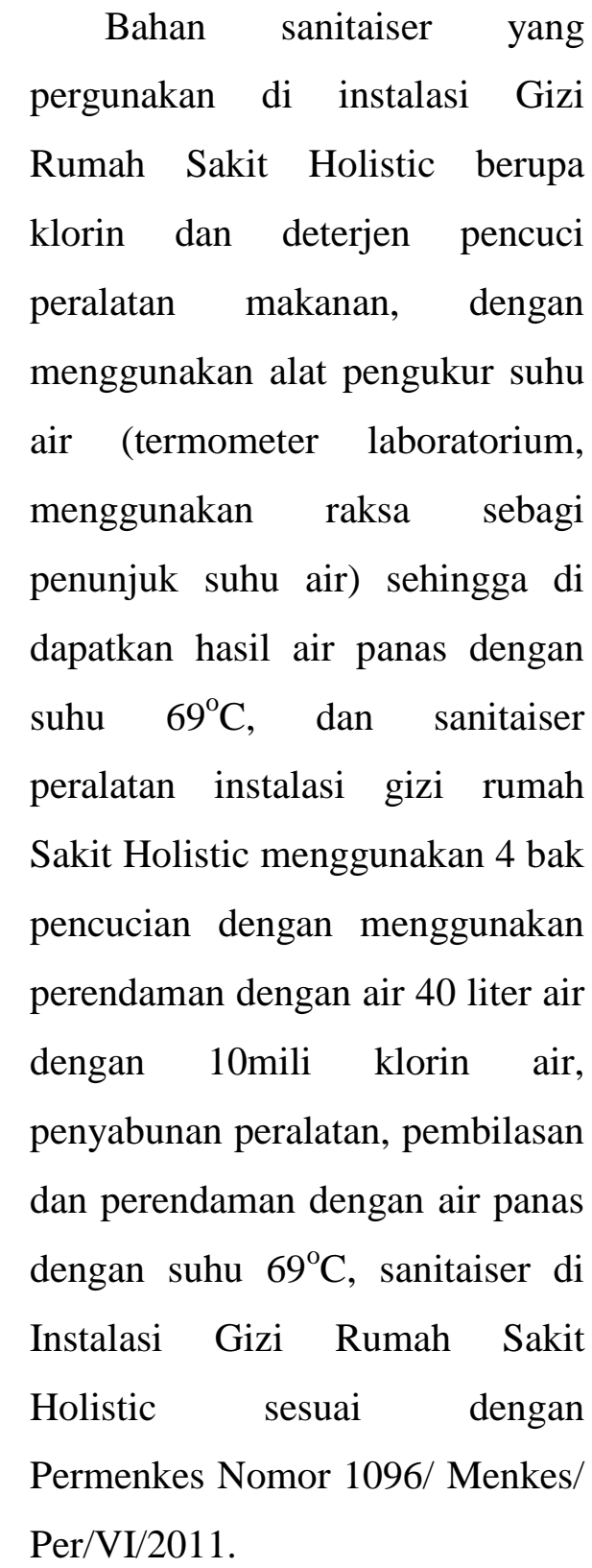

\section{e. Sanitaiser Peralatan}

Dan sanitaiser peralatan instalasi gizi rumah Sakit Holistic menggunakan 4 bak pencucian dengan menggunakan perendaman dengan air 40 liter air dengan 10mili klorin air, penyabunan peralatan, pembilasan dan perendaman dengan air panas dengan suhu $69^{\circ} \mathrm{C}$

\section{Higiene Penjamah Makanan}

\section{a. Kesehatan Penjamah}

Dari hasil observasi higiene penjamah makanan Instalasi Gizi Rumah Sakit Holistic di ketahui sebagai berikut: sebanyak 5 (38\%) penjamah makanan laki-laki memiliki rambut pendek atau rapi 8 (61\%) penjamah perempuan memakai hijab rapih, dari 13 (100\%) penjamah semua menjaga kebersihan tangan dan kuku, dipotong pendek, bersih dan bebas dari kutek dan pada saat observasi pengolahan makanan tidak terdapat luka pada kulit atau tangan, untuk semua penjamah makanan saat ini belum bisa di buktikan mempunyai penyakiat menular seperti TBC, kolera, tipus, hepatitis, dikarenakan 13 (100\%) penjamah makanan 
belum mengulang pemeriksaan usap dubur atau (rectal swab).dan selain itu semua penjamah makanan belum mempunyai sertifikat kesehatan.

b. Pemakaian

APD

(Alat

\section{Pelindung Diri)}

Dari hasil observasi higiene penjamah makanan Instalasi Gizi Rumah Sakit Holistic di ketahui sebagai berikiut: 3 (23\%) penjamah makanan menggunakan apron atau celemek ketika pengolahan makanan sedangkan 10 (76\%) penjamah hanya memakai baju kerja atau baju APD yang fungsinya sama dengan apron atau celemek, $8 \quad(61 \%)$ penjamah menggunakan alat pelindung rambutmemakai hijab,5 (38\%) penjamah lainnya tidak menggunakan pelindung rambut, $13(100 \%)$ penjamah menggunakan alat pelindung kaki atau sepatu dapur sedangkan, 8 (61\%) penjamah menggunakan alat pelindung tangan atau sarung tangan ketika pengolahan berlangsung dan saat penyajian makanan matang sedangkan 5 (38\%) penjamah merasa malas memakai sarung tangan ketika pengolahan dan penyajian makanan berlangsung, 13 (100\%) penjamah tidak menggunakan alat pelindung pernapasana dikarenakan menghambat pernapasan pekerjaanketika pengolahan dan penyajian makanan berlangsung.

\section{Perilaku Penjamah Makanan}

Dari hasil observasi higiene penjamah makanan Instalasi Gizi Rumah Sakit Holistic di ketahui sebagai berikut: 1(7\%) penjamah makanan menggaruk anggota badan pada saat pengolahan berlangsung 12 (92\%) lainya tidak dan fasilitas yang bukan untuk keperluannya dan 8 (61\%) yang menggunakan sendok atau garpu ketika mencicipi makanan $5 \quad(38 \%)$ lainya menggunakan pengaduknya langsung dan hanya 6 (46\%) penjamah makanan yang 
menggunakan

penjepit

makanan ketika kontak

langsung dengan makanan, 7

(53\%) lainya memakai tangan

terbuka dan $13(100 \%)$ tidak

merokok di dalam atau di luar

ruangan.

\section{Pengetahuan}

Penjamah

\section{Makanan}

Dari hasil wawancara penjamah makanan di Instalasi

Gizi Rumah Sakit Holistic

Purwakarta sudah mengetahui pelaksanaan higiene dan sanitasi di instalasi gizi. Dari pengetahuan penjamah makanan sudah $100 \%$ mengerti tentang higiene dan sanitasi di karenakan adanya penyuluhan tentang higiene dan sanitasi oleh Ketua Instalsi Gizi dan dengan dilengkapinya petunjuk-petunjuk higiene sanitasi di setiap tempat.

4. Menganalisa Uji Laik Higienen Penjamah Makanan dan Sanitasi Lingkungan Instalasi Gizi Rumah Sakit Holistic

Tabel 4.5 Uji laik fisik untuk Higiene Penjamah Makanan dan Sanitasi Lingkungan di Instalasi Gizi Rumah Sakit Holistic Purwakarta

\begin{tabular}{llcc}
\hline NO & \multicolumn{1}{c}{ URAIAN } & BOBOT & X \\
\hline 1 & URAIAN UMUM & & \\
\hline & Jumlah & $\mathbf{6 0}$ & $\mathbf{5 8}$ \\
\hline 2 & URAIAN KHUSUS GOLONGAN A.1 & & $\mathbf{6 3}$ \\
\hline & Jumlah & $\mathbf{7 0}$ & \\
\hline 3 & KHUSUS GOLONGAN A.2 & $\mathbf{7 4}$ & $\mathbf{6 7}$ \\
\hline & Jumlah & & $\mathbf{7 6}$ \\
\hline 4 & KHUSUS GOLONGAN A.3 & $\mathbf{8 3}$ & \\
\hline & Jumlah & & $\mathbf{8 3}$ \\
\hline 5 & KHUSUS GOLONGAN B & $\mathbf{9 2}$ & \\
\hline
\end{tabular}

Dari hasil penilaian dengan menggunakan tabel uji laik fisik untuk higiene penjamah makanan dan sanitasi lingkungan di Instalasi Gizi Rumah Sakit Holistic
Purwakarta mendapatkan hasil $83(92 \%)$ oleh karna itu Instalasi Gizi Rumah Sakit Holistic sudah memenuhi penilaian laik higiene sanitasi golongan $\mathrm{B}$, minimal 
nilai 83 maksimal 92, atau rangking $83-92 \%$.

\section{PEMBAHASAN}

Berdasarkan hasil penelitian yang berjudul "Pelaksanaan Higiene Penjamah Makanan dan Sanitasi Lingkungan di Instalasi Gizi Rumah Sakit Holistic Purwakarta" didapatkan sebagai berikut pelaksanaan sanitasi di instalasi gizi Rumah Sakit Holistic Purwakarta yang meliputi: Sanitasi Bangunan, Sanitasi Ruangan Pengolahan Makanan, Aspek sanitasi rumah sakit, Bahan Sanitaiser, Sanitaiser Peralatan dan Higiene penjamah makanan meliputi: Kesehatan Penjamah,Pemakaian APD, perilaku penjamah makanan. Menurut Permenkes Nomor 1096/Menkes/Per/VI/2011 tentang higiene Sanitasi Jasaboga adalah upaya untuk mengendalikan faktor risiko terjadinya kontaminasi terhadap makanan, baik yang berasal dari bahan makanan, orang, tempat dan peralatan agar aman dikonsumsi.

\section{Sanitasi Lingkungan Instalasi Gizi}

a. Sanitasi Bangunan.

Halaman terpampang papan nama perusahaan dan adanya nomor izin usaha serta nomor sertifikat laik higiene sanitasi ini menandakan perusahaan tersebut sudah memiliki sertifikat laik higiene sanitasi dari departeman kesehatan. ini juga bisa memudah perusahaan untuk sertifikasi atau mengurus perijinan tentang higiene sanitasi itu sendiri.Pintu dan Jendela insatalasi gizi harus dibuat membuka ke arah luar dan dapat menutup sendiri (self closing), dilengkapi peralatan anti serangga atau lalat seperti kassa, pintu rangkap dan lain-lain, ini di karenakan ruangan instalasi gizi harus terhindar dari cemaran debu dan serangga yang memungkinkan bisa masuk dan mencemari makanan. ${ }^{3}$ 
b. Sanitasi

Ruangan

\section{Pengolahan Makanan.}

Sudut dinding dengan lantai harus berbentuk lengkung (conus). Ini dikarenakan memudahkan dalam pembersihan dari kotoran dan bakteri yang terbawa debu yang bersumber dari kotoran seperti bakteri semisal Bacteroides dan Faecalibacterium bakteri ini debu yang bisa menempel pada dinding dengan lantai yang konus yang bisa mengakibatakan penyekit diare. $^{3}$

\section{c. Aspek sanitasi rumah sakit.}

Tempat sampah harus memiliki tutup yang bisa di buka tutup. Supaya untuk menghindari keluarnya bauyang dikeluarkan sampah dan dapat menghindari kemungkinan tercemarnya makanan oleh sampah. d. Bahan Sanitaiser dan Sanitaiser Peralatan

Untuk bahan sanitaiser dan sanitaiser peralatan sudah sesuai dengan SOP (Standart Oprating procedure) yang berlaku di Instalasi Gizi Rumah Sakit Holistic Purwakarta.

\section{Higiene Penjamah Makanan}

\section{a. Kesehatan Penjamah}

Untuk semuah penjamah makanan saat ini belum bisa di buktikan mempunyai penyakit menular seperti TBC, kolera, tipus, hepatitis, dikarenakan 13(100\%) penjamah makanan belum mengulang pemeriksaan usap dubur atau (rectal swab) dan selain itu semua penjamah makanan belum mempunyai sertifikat kesehatan.

Dilakukannya pemeriksaan pemeriksaan usap dubur atau (rectal swab) untuk mengisolasi dan idertifikasi kuman pathogen (gastroenteritis) pada saluran pencernaan dan dilakukanya pemeriksaan lain seperti TBC, 
kolers, tipus dan hepatitis ini membuktikan penjamah terbebas dari penyakit menular atau pembawa penyakit (karier).

\section{b. Pemakaian APD}

(Alat

\section{Pelindung Diri)}

Penjamah menggunakan alat pelindung tangan atau sarung tangan ketika pengolahan berlangsung dan saat penyajian makanan matang sedangkan di dalam pemakaian APD, Penjamah tidak menggunakan alat pelindung pernapasana.

\section{Perilaku Penjamah Makanan dan Pengetahuan Penjamah Makanan}

Suka menggaruk anggota badanpada saat pengolahan, banyak berbicara dan menutup mulut pada saat batuk atau bersin dengan menjauhi makanan atau keluar dari ruangan,tidak makan atau mengunyah selama bekerja, memakai perhiasan, kecuali cincin kawin yang tidak berhias (polos) dan Menggunakan sendok atau garpu ketika mencicipi makanan ini kontaminasi atau cemaran lainya bisa di sebabkan dari kebiasaan atau perilaku penjamah makanan.

4. Menganalisa Pelaksanaan laik Higienen Penjamah Makanan dan Sanitasi Lingkungan Instalasi Gizi Rumah Sakit Holistic

Alat pembuangan asap dilengkapi filter (penyaring), ini di karenakan mencegah masuknya debu dan kotoran dari luar yang bisa mencemari maknan.Dari hasil penilaian dengan menggunakan tabel uji laik fisik untuk higiene penjamah makanan dan sanitasi lingkungan di instalasi gizi Rumah Sakit Holistic Purwakarta mendapatkan hasil $83(92 \%)$ oleh karna itu instalasi gizi Rumah Sakit Holistic sudah memenuhi penilaian laik higiene sanitasi golongan $\mathrm{B}$, minimal nilai 83 maksimal 92, atau rangking 83 $92 \%$. 
SIMPULAN

Sanitasi bangunan, sanitasi ruangan pengolahan makanan, aspek sanitasi Rumah Sakit, bahan sanitaiser, sanitaiser peralatan. Sudah memenuhi syarat menurut Permenkes Nomor 1096/ Menkes/Per/ VI/2011 dan SOP (Standart Oprating procedure) yang berlaku di instalasi. Higiene penjamah makanan meliputi: kesehatan penjamah, pemakaian APD (Alat Pelindung Diri), perilaku penjamaha makanan sudah memenuhi syarat menurut Permenkes Nomor 1096/Menkes/Per/VI/2011 dan SOP (Standart Oprating procedure) yang berlaku di instalasi. Menganalisis pelaksanaan laik higiene dan sanitasi di instalasi gizi Rumah Sakit Holistic
Purwakarta dengan Permenkes Nomor 1096/Menkes/Per/VI/2011 sesuai dengan SOP (Standart Oprating procedure) yang berlaku di instalasi dan golongan B, yaitu 83 $(92 \%)$.

\section{DAFTAR PUSTAKA}

1. Depkes. Pedoman Penyelenggaraan dan prosedur Rekam Medis Rumah Sakit di Indonesia. Jakarta: Departemen Kesehatan RI; 2006.

2. Notoatmodjo, S. Metodologi Penleitian Kesehatan. Jakarta: Rineka Cipta; 2012.

3. Budiyanto. Peranan

Mikroorganisme dalam

Kehidupan Kita. Malang: Universitas Muhammadiyah Malang; 2001. 